\title{
A Retrospective Study of Conservative Treatment of Gastric Dilatation-Volvulus in the Dog
}

\author{
By A.V. Eggertsdóttir and L. Moe \\ Department of Small Anımal Clınıcal Sciences, Norwegıan College of Veterinary Medicıne, Oslo, Norway.
}

\begin{abstract}
Eggertsdóttir, A.V. and L. Moe: A retrospective study of conservative treatment of gastric dilatation-volvulus in the dog. Acta vet. scand. 1995, 36, 175-184. - A retrospective study of 103 dogs with gastric dilatation-volvulus (GDV) treated conservatively during the period 1985-1989 was performed. The date and number of recurrences, and the date and cause of death along with breed, age and sex were collected from clinic records and from a questionnaire sent to the owners ( $77 \%$ response). The treatment consisted of emptying the stomach with a stomach tube, gastrocentesis if necessary and treating shock.

All of the affected dogs were from moderate to large sized breeds and the study showed that particular breeds appear to be predisposed to GDV. The average age was 7.2 years and there was no gender predisposition. Sixty-six per cent of the dogs survived the initıal treatment and $50 \%$ of the dogs were still alıve 1 month after treatment. Thirty-nıne dogs $(71 \%)$ received recurrence between 5-760 days after initıal treatment. Fifty-six per cent had recurrence withın 3 months and all except 2 dogs, withın 1 year. Data for the time of death, regardless of cause, was available for $68 \mathrm{dogs}$. Of these $59(81 \%)$ died within a year after initıal treatment. Conservative treatment was found to be an adequate life-saving procedure in the acute stage of GDV, but could not alone prevent recurrence of the disease.
\end{abstract}

torsion; syndrome; non-surgical treatment.

\section{Introduction}

Gastric dilatation-volvulus (GDV) is a disease of dogs that, if untreated rapidly leads to a state of shock and death. It therefore demands immediate treatment, which, in addition to being life-saving, should also prevent recurrences. Many theories exist concerning the aetiology of GDV. Some of the factors considered significant for development of the condition are anatomical predisposition, overeating, stress and physical activity just before and after feeding (Lippencott et al. 1989, Burrows et al. 1990).

Several surgical methods for emptying, repositioning and fixation of the stomach have been described. Among these methods are pyloromyotomy, tube gastrostomy, circumcostal gastropexy, belt-loop gastropexy, fundic gastropexy and incisional gastropexy (Matthiesen 1983, Leib et al. 1985, Woolfson et al. 1986, Whitney et al. 1989, Frendin et al. 1990, Ellison 1993). In contrast conservative treatment consists of emptying the stomach with a stomach tube, possibly accompanied also by gastrocentesis (Funquist 1969, Dann 1976, Funquist et al. 1979, Baumberger et al. 1981, Meyer-Lindenberg et al. 1993).

This paper presents the breed, age and sex distribution, and the survival and recurrence rates in 103 conservatively treated cases on initial appearance of the disease. 


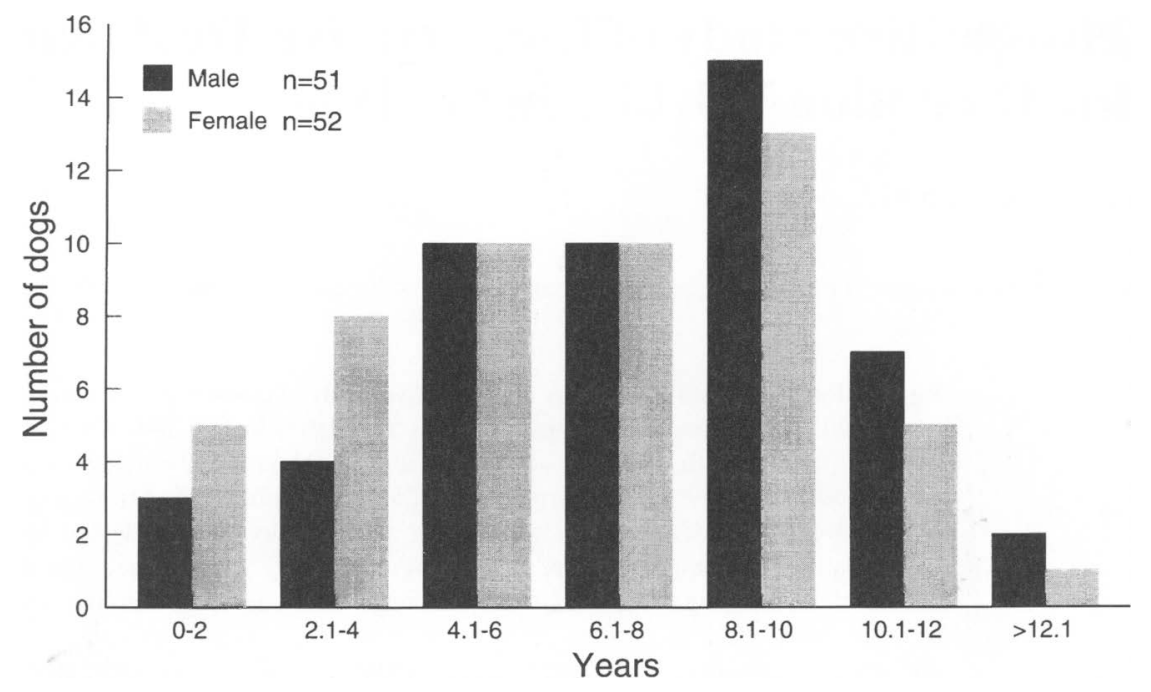

Figure 1. Distribution by age and sex of 103 dogs with gastric dilatation-volvulus between 1985-1989.

\section{Materials and methods}

The material consists of 103 dogs from 26 breeds with GDV, that were treated or attempted treated without surgery at the outpatient clinic of the District Veterinarian in Oslo during the period 1985-1989. The clinic was open between 1600 and 0800 on week days and throughout the day during weekends and holidays. All the dogs were therefore treated during the evening, night or on weekends by 10 different veterinarians. The dogs were not hospitalized routinely, since the clinic does not have an intensive care unit. The data were compiled from clinic records over a 5-year period and from a questionnaire sent to the 70 owners of dogs surviving the acute attack. The owners of $54 \mathrm{dogs}(77 \%)$ replied to the questionnaire. The time period between the initial treatment and reply to the questionnaire varied from 10-70 months. If the owner did not answer $(n=16)$, or if the clinic record indicated that the dog was dead or euthanized in association with treatment $(n=25)$, information was confined to that available in the clinic record. Dogs that died or were euthanized before treatment started were included in the demographic data $(\mathrm{n}=8)$ (Fig. 1 and 2).

In addition to breed, age and sex, the effect of treatment, suvival time, number of recurrences and the results of treatment of the recurrences were recorded. Information on the owner's own follow up treatment was also collected. This information was unfortunately incomplete and unsuitable for further analysis. The diagnosis of GDV was based on a clinical examination of the animal. All of the dogs had distended and gas-filled stomachs which they were unable to empty, and had in addition developed variable degrees of shock.

Radiographic examination to differentiate between dilatation and torsion was not conducted routinely, nor was electrocardiography. Blood samples for biochemistry or haematology were not collected routinely either. Treatment consisted of emptying the contents 


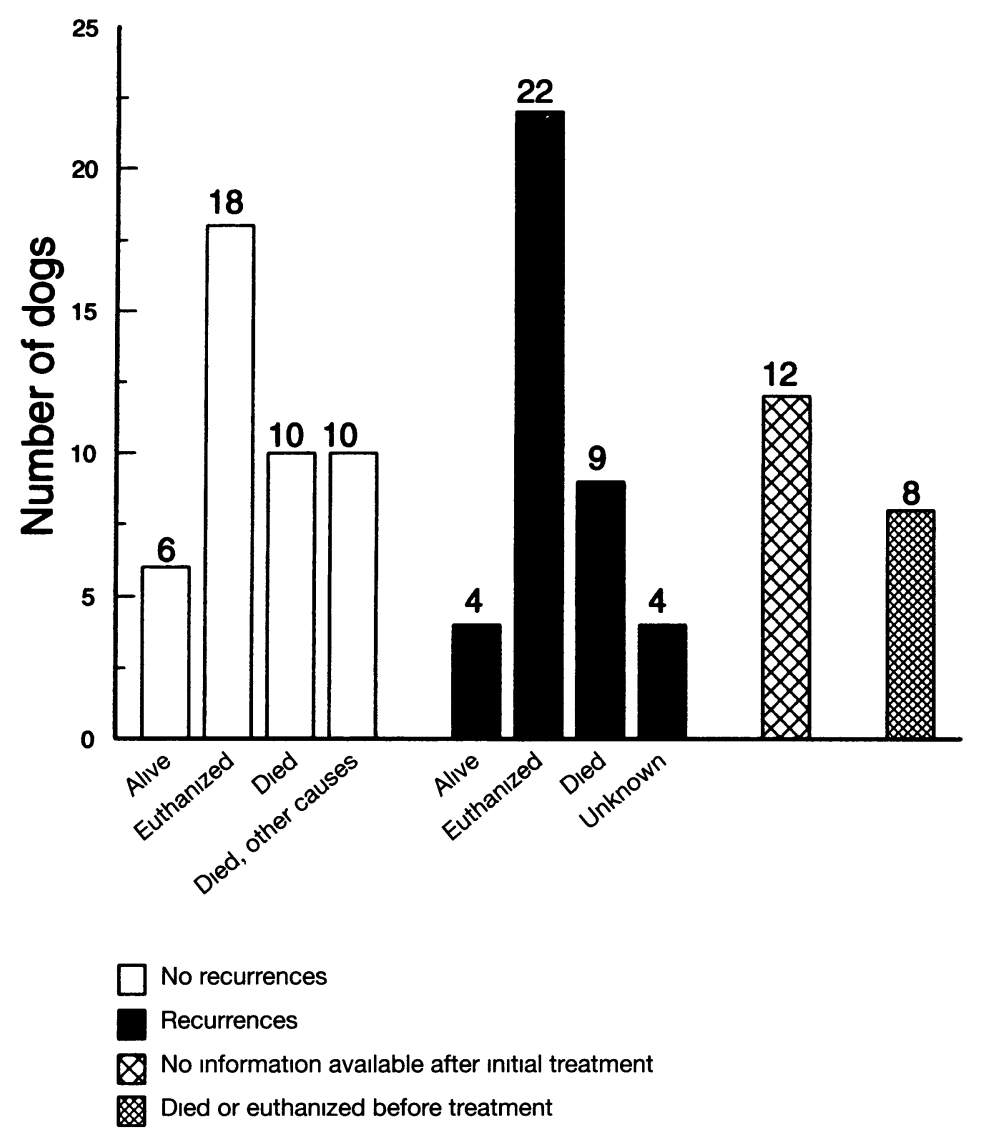

Figure 2. The final outcome of 103 dogs with gastric dilatation-volvulus between $1985-1989$, at the time of censorıng (November 1990).

of the stomach. In cases of a moderately distended stomach, it was attempted to pass a stomach tube. If this was successful, the contents were removed, often with the aid of a suction pump. In addition, the stomach was flushed with water through the stomach tube. If intubation was not possible, the stomach was punctured percutaneously with a venous catheter (Venflon 2, $1.2 \mathrm{~mm}$; Braun) The puncture was conducted over the most prominent and gas-filled part of the stomach, preferably in the right flank. After evacuation of gas, another attempt to pass a stomach tube was made. In cases with advanced stomach distension, puncture was often conducted immediately, before intubation was attempted. If treatment was still unsuccessful, the dogs received gastrostomy and were not included in the study ( 2 cases). Most of the dogs were also treated for shock by intravenous administration of fluid (Sodium Chloride 0.9\%; Kabi Pharmacia or lactated Ringer; Kabi Pharmacia). Corticosteroids and antibiotics were not routinely given. Extremely distressed dogs 


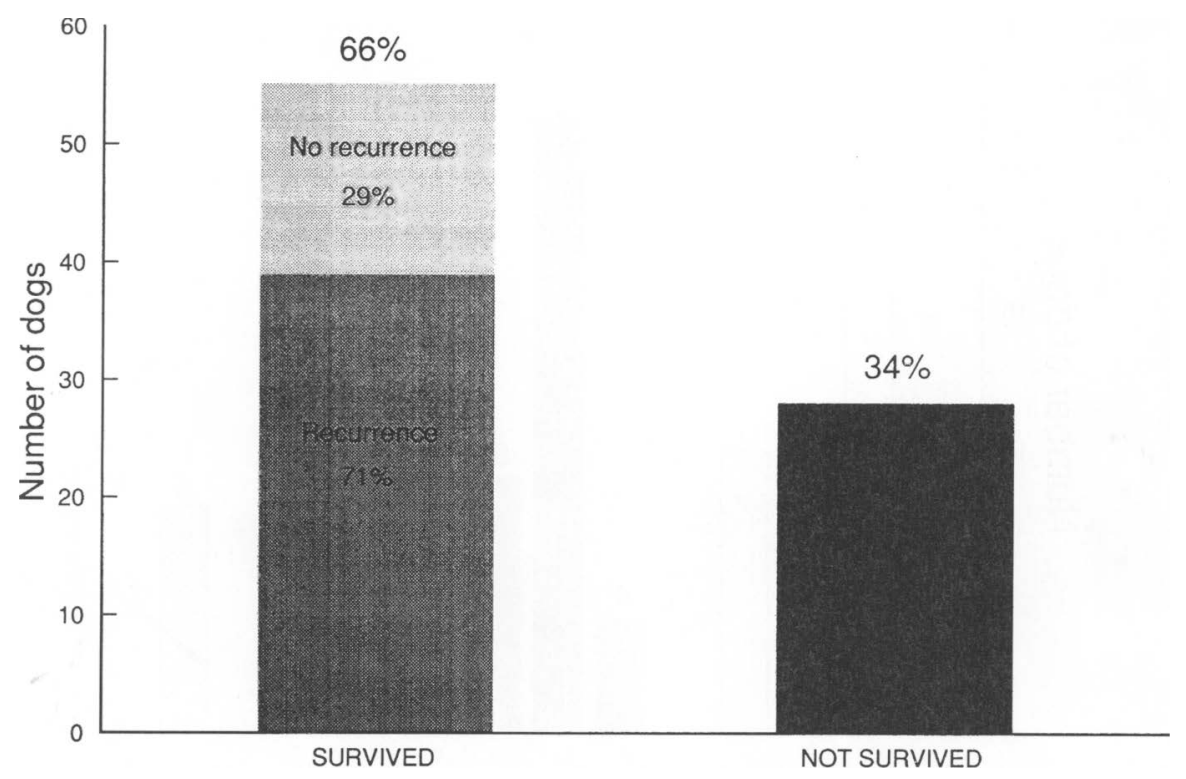

Figure 3. Number of dogs that survived the initıal treatment of gastric dilatation-volvulus. Number of recurrences are also indicated. Data were avallable for 83 dogs.

were sedated with propionylpromazine (Combelen; Bayer), 0.25-0.5 mg/kg subcutanously or intravenously.

After treatment the animals were released and the responsibility for subsequent surveillance and follow-up treatment was placed on the owner. Upon discharge, the owner was given instructions to return immediately if abdominal distention reoccurred and how to feed and care for the dog after treatment. The recommendations were to feed the dog 3-4 times daily with easily digestible food, for example, boiled fish and rice. After several weeks, the dog could be gradually transferred to normal diet again, but still with the daily ration divided over several meals. It was also recommended to restrict and divide the daily intake of water and to avoid excessive physical activity for $1-2 \mathrm{~h}$ before and after feeding. In this study a recurrence is defined as a new episode of GDV that occurs more than 4 days after the initial appearance. A relapse that occurred between 1-4 days is treated as a complication to the first episode.

\section{Results}

The sex and age distributions of affected dogs are shown in Fig. 1. The age of the dogs at initial treatment varied from 1-15 years, with an average of 7.2 years, while the sex distribution was even. The Doberman $(n=19)$, German Shepherd $(n=15)$, German Pointer $(n=11)$, Great Dane $(\mathrm{n}=8)$ and Greenland Dog $(n=6)$ breeds comprised $57 \%$ of the dogs in the study.

The outcome of all the dogs in the study at time of censoring is presented in Fig. 2. After initial treatment no further information could be obtained for $12 \%$ of the cases and they were therefore not included in further calculations. Eleven per cent died of other causes than GDV and $40 \%$ of the dogs died or were 


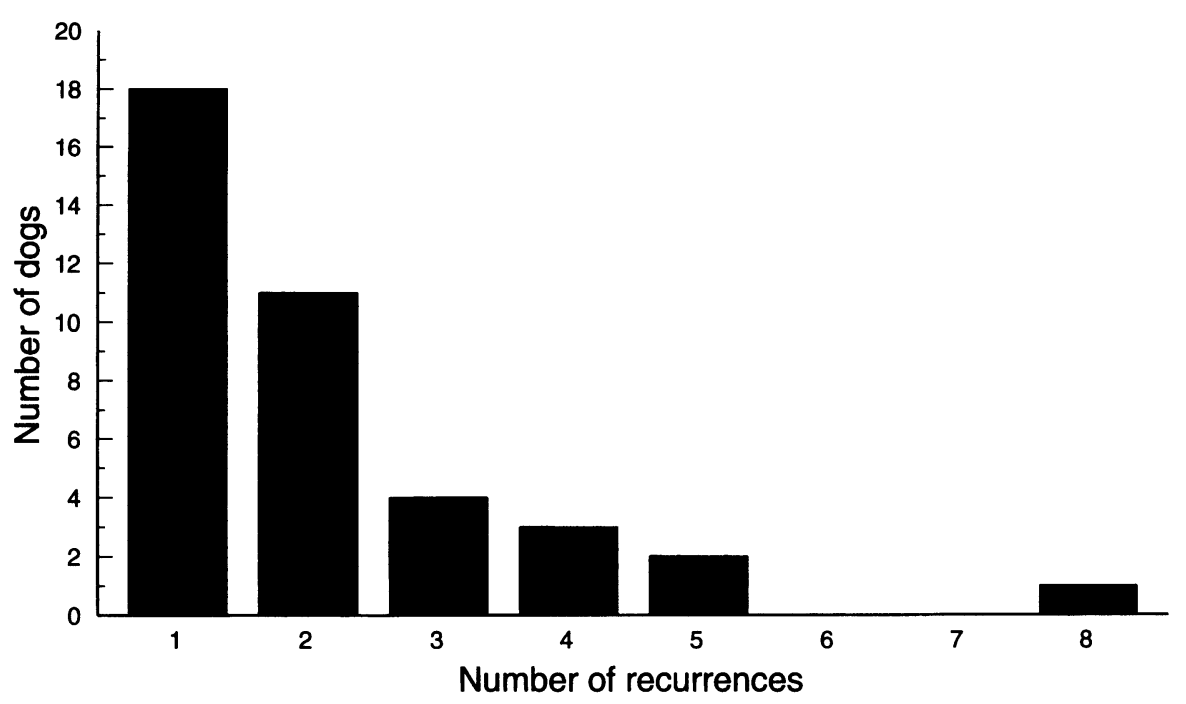

Figure 4. Number of recurrences in 39 dogs treated for gastric dilatation-volvulus between 1985-1989.

euthanized in connection with the initial treatment. Ten dogs $(11 \%)$ were still alive at the time of censoring and 4 of these had had recurrences. There was no information available on earlier episodes of GDV in the 8 dogs that were euthanized before treatment could be commenced. In 53\%, GDV occurred only once, while $47 \%$ had 1 or more recurrences of the disease.

Having excluded 8 dogs, that were euthanized or died prior to treatment and 12 dogs with no information after initial treatment, this left 83 dogs that were considered clinically fit for treatment and with sufficient data to be further analyzed. Fifty-five (66\%) of the dogs survived the first episode (Fig. 2 and 3). Sixteen of these dogs $(29 \%)$ never developed GDV again. The median follow-up time for these dogs was 720 days and the mean age at the time of diagnosis was 7 years. Thirty-nine of the dogs that survived the first episode (71\%) received subsequent recurrence between 5-760 days after initial treatment.

The number of recurrences is presented in
Fig. 4. Fifty-four per cent of these dogs had multiple recurrences.

Fig. 5 shows the number of months between the initial treatment and the first recurrence. Fifty-six per cent of the dogs had recurrences within 3 months and all except 2 , within 1 year. The time of the first recurrence was not available for 3 dogs.

The survival time after initial treatment is given in Fig. 6 . This figure shows that $50 \%$ of the dogs were dead or euthanized within 1 month of the initial treatment and $75 \%$ within 8 months.

Twenty-eight dogs died or were euthanized within 4 days after the initial treatment. The mean age was 7 years.

\section{Discussion}

This retrospective study presents a disheartening picture of the long-term outcome if conservative treatment is used solely in treating GDV patients. Both the recurrence and long term mortality rates were high (Fig. 5 and 6). Sixty-seven dogs $(77 \%)$ in the study died or 


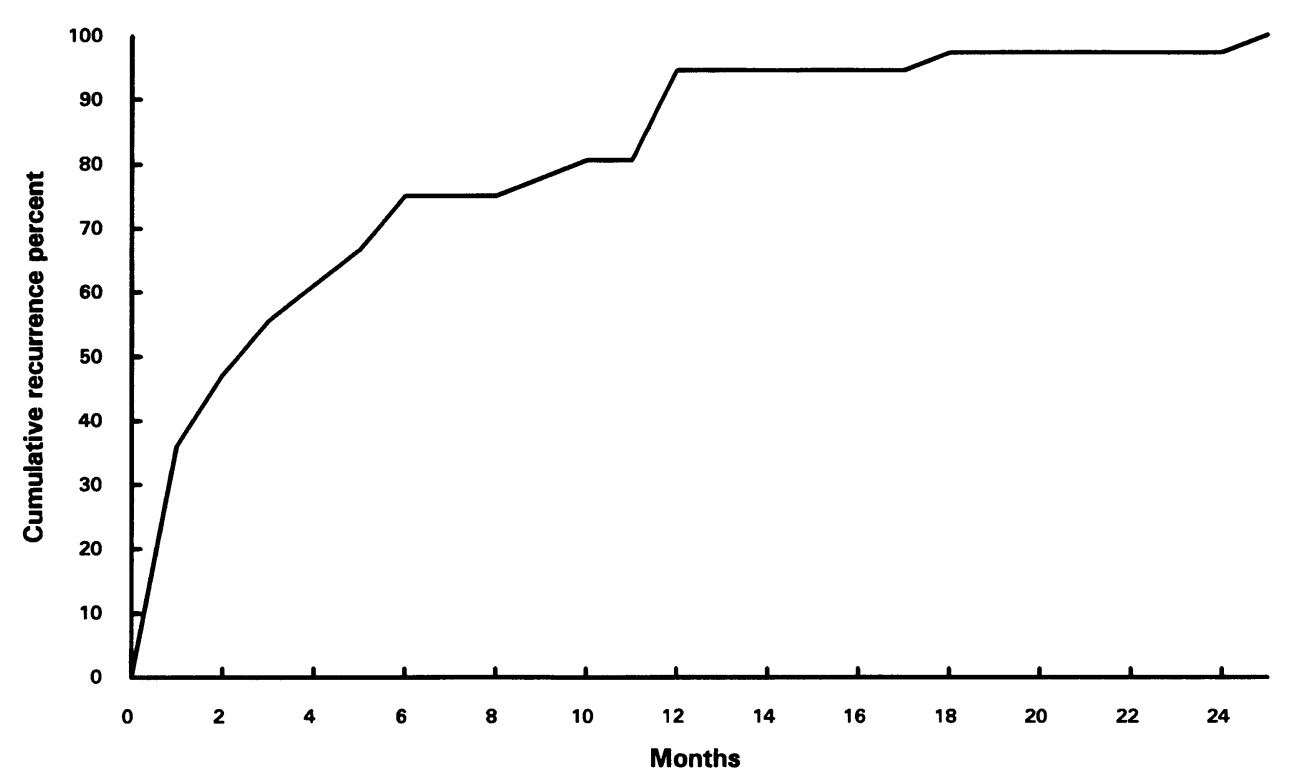

Figure 5. Number of months between the first treatment of gastric dilatation-volvulus and the first recurrence. Data were available for 36 dogs.

were euthanized due to GDV. Among these dogs $73.5 \%$ died within 1 year and $89 \%$ were dead within 2 years of the initial treatment. On the other hand, the study showed that $66 \%$ of the dogs survived the initial treatment (Fig. 3). This figure is probably an underestimate, since 12 dogs surviving initial treatment were excluded due to lacking follow-up information. If included, these dogs would increase the success of conservative treatment to $71 \%$. The method is therefore an adequate life-saving procedure together with intensive shock therapy. This treatment will probably be most successful if the dog is presented early, with only a moderately inflated stomach, and is not seriously affected systemically.

Published studies of conservative treatment of dogs with GDV (Funquist 1969, Dann 1976, Funquist et al. 1979, Baumberger et al. 1981, Meyer-Lindenberg et al. 1993) are usually based on a small number of dogs or short fol- low-up times and selection of data, making them difficult to compare with this study.

In a retrospective study of 211 dogs with GDV treated surgically at the Norwegian College of Veterinary Medicine between 1971-1985 the mortality rate was high $(72 \%)$. That included 106 dogs that died before treatment started or within few days post treatment and 27 dogs that died from recurrence of GDV. Data was not available for $27 \mathrm{dogs}$ and the mean follow up time was 2.4 years (Fjeld et al. 1988). Although this was a surgical method of treatment, it is relevant to compare the 2 results because no fixation of the stomach was performed during surgery, and the patient material came from the same geographic area and population of dogs, but at different time periods. With these reservations in mind dogs treated conservatively have an equal probability of survival as dogs treated surgically without gastropexy. Since conservative treat- 


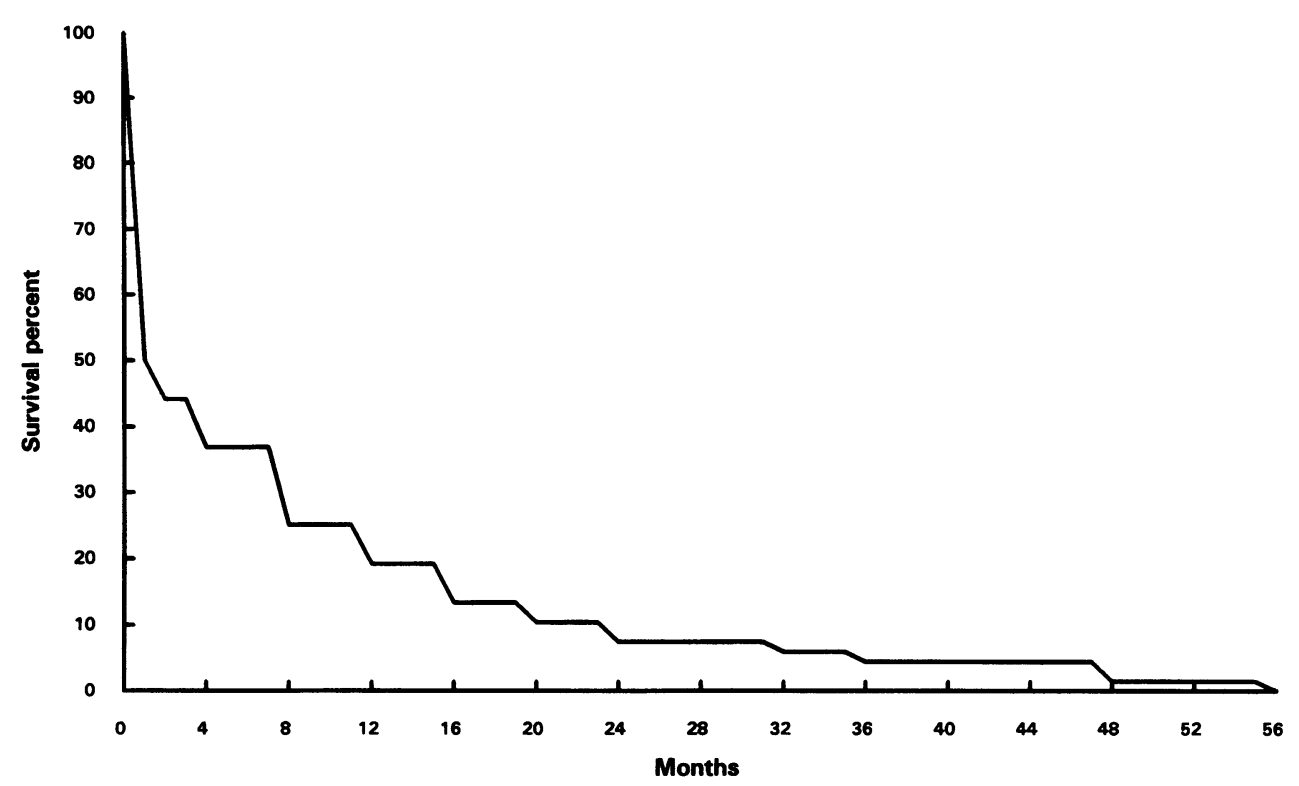

Figure 6 Number of months between the first treatment of gastric dilatation-volvulus and death, regardless of cause. Data were avallable for 68 dogs.

ment is less demanding and in most cases faster than surgery, it is therefore to be preferred in the majority of cases presented during the acute phase of the disease. Each case must however be evaluated separately and some cases must, of course, be treated surgically immediately.

Other studies have showed that most dogs with life-threatening or irreversible damage after GDV die in the course of 4 days (Betts et al. 1974, Matthiesen 1983). This was therefore considered the basis for our definition which differentiates between recurrence and complication. A dog that survives an acute treatment for longer than this period, should have a good chance of tolerating further treatment aimed at preventing recurrences. This study showed that such treatment should be performed as soon as the dog is properly stabilized and within a month of the acute treatment.
The high rate of recurrence has been one of the headaches in the treatment of GDV (Betts et al. 1974, Dann 1976, Baumberger et al. 1981, Lelb et al. 1985, Whitney et al. 1989, Ellison 1993). Seventy-one per cent of the 55 dogs surviving the initial treatment in this study had recurrences (Fig. 3). All of the dogs, apart from 2 , had recurrences within a year. Thirtysix per cent relapsed within a month and $56 \%$ within 3 months (Fig. 5). Other authors have recorded recurrence frequencies of almost $80 \%$ among dogs with GDV that were treated without gastropexy (Whitney et al. 1989, Ellison 1993).

Many authors maintain that treatment for GDV that does not include fixation of the stomach is to be considered first-aid that cannot prevent a recurrence (Lelb et al. 1985, Woolfson et al. 1986, Lippencott et al. 1989, Whitney et al. 1989, Frendin et al. 1990, Ellison 1993). The present study confirmed this. Four 
dogs (10\%) survived the recurrence (Fig. 2), compared to $19 \%$ of the dogs referred to in the Norwegian study of surgically treated cases (Fjeld et al. 1988). Because GDV is a very dramatic and painful disease for the dog, many of the owners (56\%) wished to have their dog euthanized upon recurrence. This was probably the main reason that so few dogs in the study survived a recurrence.

Mortality is high in the acute phase of GDV, regardless of the method of treatment chosen (Muir 1982, Leib et al. 1984). In the present study, the combined mortality rate for the period before or during the first treatment was $40 \%$. There are few figures in the literature concerning the mortality of GDV in the first hours of the disease, but we assume that nearly all cases of GDV will die without treatment. Many factors contribute to the mortality rate, among others the owner's knowledge and awareness of the first symptoms of the disease, and the distance to and availability of veterinary service. Such factors vary a lot between countries and societies. In 3 other retrospective studies, involving 75-160 dogs each and a number of different treatments, the mortality varied from $27 \%-43 \%$ (Betts et al. 1974, Muir 1982, Matthiesen 1983). Among the dogs referred to in the Norwegian study of surgically treated cases, $50 \%$ of the dogs that died or were euthanized in connection with the treatment, were not included in the data which reduces the mortality rate from $72 \%$ to $35 \%$. In the present study however, all cases presented to the clinic were included. The data were collected in an out-patient clinic, that was open for emergencies during the evenings, nights and weekends, open to the general public, and received acutely diseased small animals from a large area. In most of the other studies the data are collected from referred cases. Longstanding cases, or cases where the owners could not afford further treatment, are seldom referred. The fact that such dogs are included in the present study may explain some of the difference in the mortality rates. In addition, the fact that the dogs were released to the owners custody and fed soon after conservative treatment may account for a number of deaths and recurrences, thereby hampering the efficacy of the conservative treatment.

Other studies have shown that particular breeds are predisposed to GDV. This study also revealed a relatively higher incidence of GDV in these same breeds and it also corresponds with previously conducted studies in regard of sex and age dispositions (Betts et al. 1974, Muir 1982, Burrows et al. 1990, Eggertsdóttir 1991).

\section{Conclusion}

Conservative treatment is an adequate lifesaving procedure in the acute stage of GDV, but it does not prevent recurrence of the disease. When comparing surgical treatment without fixation with conservative, in the acute stage of GDV, there seems to be no differences in the mortality or recurrence rates. Low recurrence rates and far better longterm survival have been reported using intensive shock therapy and gastropexy (Leib et al. 1985, Woolfson et al. 1986, Whitney et al. 1989, Frendin et al. 1990). But there is a lack of controlled experiments that support the hypothesis that gastric fixation gives a better longterm survival than no fixation, given the same intensive shock and supportive treatment.

\section{Acknowledgement}

The authors wish to thank our colleagues W. Bredal, A. Indreb $\varnothing$ and S. Thoresen for constructive criticism and support. 


\section{References}

Baumberger A, Lakatos L: Der Magenblahungs-Magendrehungs-Komplex beim Hund: Behandlungsergebnısse und Rezıdıvhaufigkeit (Gastric dilatation-volvulus in the dog: results of treatment and recurrence rate). Schwe1z. Arch. Tierhelk. 1981, 123, 429-433.

Betts $C W$, Wingfield WE, Green $R W$. A retrospective study of gastric dilation-torsion in the dog. J. small Anim. Pract 1974, 15, 727-734.

Burrows CF, Ignaszewskı $L A \cdot$ Canine gastric dilatation-volvulus. J. small Anim. Pract. 1990, 31, 495501.

Dann JR. Medical and surgical treatment of canine acute gastric dilation. J. Amer. Anım. Hosp. Ass. 1976, 12, 17-22.

Eggertsdóttur AV: Mageutvidelse/magedreınıng (Gastric dilatation-volvulus). In: (Dog breeding and health). Indreb $\varnothing$ A (ed): Hund- Avl og Helse. Smådyrpraktıserende Veterınærers Forenıng, Oslo, 1991, pp 143-148.

Ellison GW. Gastric dilation volvulus surgical prevention Vet Clın N Amer small Anım. Pract. 1993, 23, 513-530.

Fjeld TO, Eggertsdóttur AV: Ventrıkkeldılatasjons/torsjonssyndromet hos hund: en retrospektıv studie av operativt behandlede kasus (Gastric dilatation-volvulus in the dog: a retrospective study of surgically treated cases) Norsk Vet.-T. 1988, 100, 281-287.

Frendin J, Funquist B: Fundic gastropexy for prevention of recurrence of gastric volvulus. J. small Anim. Pract. 1990, 31, 78-82.

Funquist $B \cdot$ Gastric torsion in the dog. Nonsurgical reposition. J. small Anım. Pract. 1969, 10, 507511

Funquist B, Garner L. Pathogenic and therapeutic aspects of torsion in the canıne stomach. J. small Anım Pract. 1967, 8, 23-32.

Funquist B, Obel N. Gastric torsion in the dog. Nonsurgical treatment by spiration of gastric contents durıng repeated rotation of the anımal. J. small Anım. Pract 1979, 20, 93-101.

Leib MS, Blass CE: Gastric dilation-volvulus in dogs an update. Comp Cont Educ. 1984, 6, 961969.

Leib MS, Konde LJ, Wingfield WE, Twedt DC. Circumcostal gastropexy for preventıng recurrence of gastric dilation-volvulus in the dog an evaluation of 30 cases. J. Amer. Vet. Med. Ass. 1985, 187, 245-248.

Lippencott CL, Schulman AJ· Gastric dilatation-vol- vulus-torsion syndrome. In: Ettınger SJ (ed) Textbook of Internal Medicine. (3rd ed), W.B. Saunders Co., Philadelphia, 1989, pp 1278-1288.

Matthiesen DT. The gastric dilatation-volvulus complex: medical and surgical considerations. J. Amer. Anım. Hosp. Ass. 1983, 19, 925-932.

Meyer-Lindenberg A, Rahlfs I, Harder A, Fehr M: Langzeituntersuchung zur konservativen und operativen Behandlung mit Rezidivprophylaxe bei der Magendilatation/-torsion des Hundes (A longitudinal study of conservative and surgical treatment and recurrence rate in dogs with gastric dilatatıon-volvulus) Kleıntıerpraxıs 1993 , $38,71-82$.

Muir WW. Gastric dilatation-volvulus in the dog with emphasis on cardiac arrythmias. J. Amer. Vet. Med Ass. 1982, 180, 739-742

Whitney WO, Scavell TD, Matthiesen DT, Burk RL. Belt-loop gastropexy: technique and surgical results in 20 dogs. J. Amer. Anım. Hosp. Ass. 1989, $25,75-83$.

Woolfson J, Kostolich M. Circumcostal gastropexy: Clinical use of the technique in 34 dogs with gastric dilatıon-volvulus. J. Amer. Anım. Hosp. Ass. $1986,22,825-830$.

\section{Sammendrag}

En retrospektiv studie av konservattv behandling ar ventrikkel-dllatasjons/torsjonssyndromet hos hund.

Artıkkelen omhandler en retrospektıv unders $ø$ kelse av 103 hunder med ventrikkel-dilatasjon/torsjon (VDT) som ble behandlet i tidsrommet 1985-1989. Behandlıngen besto 1 å tømme ventrikkelen med magesonde, tappe gass med kanyle og behandle sjokksymptomer. Det ble registrert behandlıngsresultat, residivfrekvens samt rase, alder og kృønn. Alle hundene 1 materialet tilhørte middelsstore eller store raser og unders $\varnothing$ kelsen viste at enkelte raser synes å være predısponerte for VDT. Gjennomsnittsalderen var 7,2 år og det var ingen kjønnsforskjell. Sekstıseks prosent av hundene overlevde behandlıngen og 50\% var fortsatt 1 live en måned etter behandlıngen. Trettı-nı hunder ( $71 \%$ ) hadde resıdıv 1 løpet av 5-760 dager etter første gangs behandling. Femtıseks prosent hadde resıdıv innen 3 måneder og bortsett fra 2 hunder, fikk alle resıdıv innen 1 år. Det forelå opplysnınger om dødsdato for 68 hunder. Av dısse døde $59(81 \%)$ innen 1 år fra første gangs behandling. 
Undersøkelsen viste at konservatıv behandlıng er en adekvat og livreddende metode $\mathrm{i}$ akuttfasen av
VDT, men den forhındrer ikke residıv av sykdommen.

(Recelved December 8, 1994; accepted January 10, 1995).

Reprınts may be obtaıned from: Anna Vigdi’s Eggertsdóttır, Department of Small Animal Clınical Scıences, Norwegian College of Veterinary Medicine, P.O. Box 8146 Dep., N-0033 Oslo, Norway. 